\title{
The Caddo Ceramic Assemblage from the New Hope Site (41FK107), Franklin County, Texas
}

Timothy K. Perttula

Heritage Research Center, Stephen F. Austin State University

Bo Nelson

Heritage Research Center, Stephen F. Austin State University

Follow this and additional works at: https://scholarworks.sfasu.edu/ita

Part of the American Material Culture Commons, Archaeological Anthropology Commons, Environmental Studies Commons, Other American Studies Commons, Other Arts and Humanities Commons, Other History of Art, Architecture, and Archaeology Commons, and the United States History Commons

Tell us how this article helped you.

This Article is brought to you for free and open access by the Center for Regional Heritage Research at SFA ScholarWorks. It has been accepted for inclusion in Index of Texas Archaeology: Open Access Gray Literature from the Lone Star State by an authorized editor of SFA ScholarWorks. For more information, please contact cdsscholarworks@sfasu.edu. 


\section{The Caddo Ceramic Assemblage from the New Hope Site (41FK107), Franklin County, Texas}

\section{Creative Commons License}

\section{(c) (1) \&}

This work is licensed under a Creative Commons Attribution-NonCommercial 4.0 International License 


\title{
The Caddo Ceramic Assemblage from the New Hope Site (41FK107), Franklin County, Texas
}

\author{
Timothy K. Perttula and Bo Nelson
}

\section{INTRODUCTION}

The New Hope sitc (41FK 107) is located on an alluvial terrace (330-340 ft. amsl) on the west side of the Big Cypress Creek valley, about $200 \mathrm{~m}$ west of the channel at the time it was inundated by Lake Bob Sandlin (Figure 1). The site covers an estimated 2.5 acres. It is about $1 \mathrm{~km}$ north of the confluence of Brushy Creek and Big Cypress Creek. In addition to what would have been the broad floodplain of Big Cypress Creek, there are gently sloping upland landforms $(340-490 \mathrm{ft}$. amsl) to the northwest, west, and south of the site, and these landforms are dissected by several intermittent streams.

Previous archaeological work at the New Hope site indicates that the landform on which it sits has been occupied on several different occasions in prehistoric times. This includes use during the Late Paleoindian, I ate Archaic, Woodland, Early Caddo, Middle Caddo, and Late Caddo period times (Nelson and Perttula 2003, 2006). The most extensive prehistoric use of the New Hope site appears to have taken place in Early and Middle Caddo period times (ca. A.D. 1000-1400); the 20-30 grave-sized looter holes and burials that have been reported to have eroded out along the shoreline at the site are evidence of Caddo

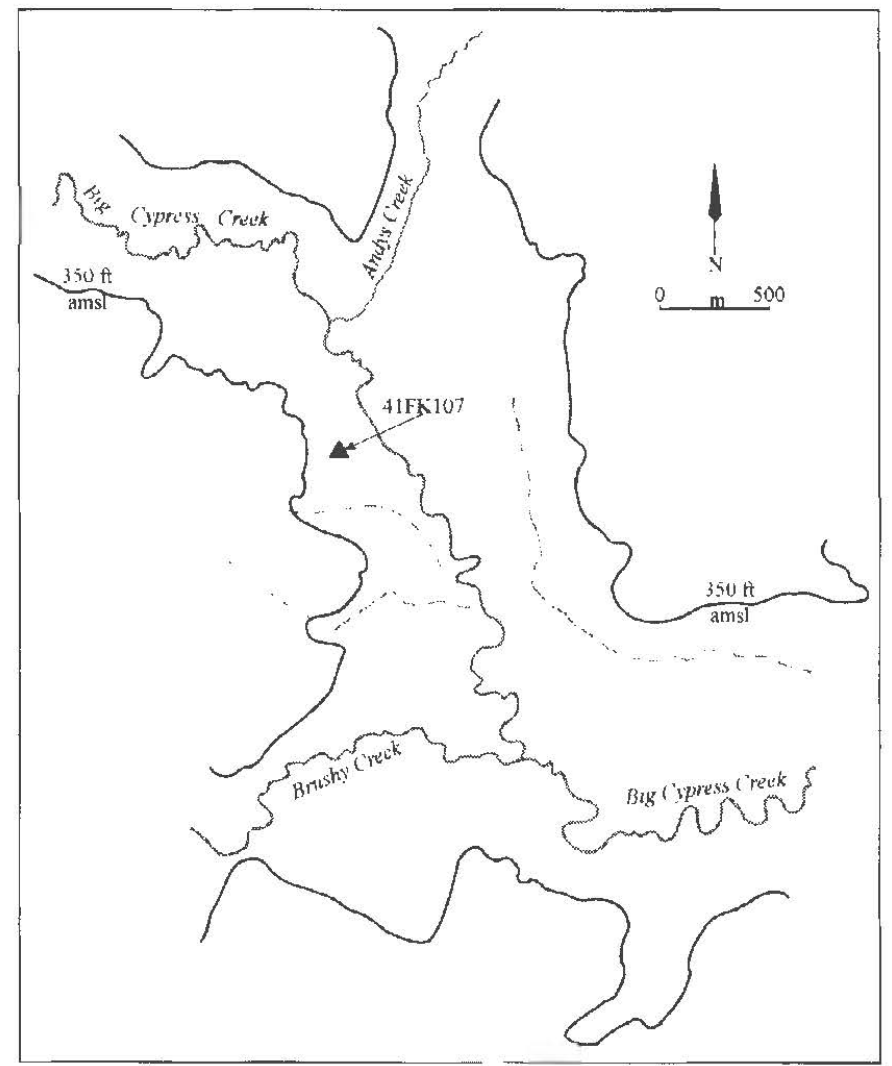

Figure 1. The location of the New Hope site in the Big Cypress Creek valley. Figure prepared by Lance Trask. cemetery use during this era (Nelson and Perttula 2003:43). The ceramic assemblages from these components have been recently documonted in a private collection, and are the subject of this article. Appendix 1 provides information on the chipped stone tools in this private collection.

\section{Environmental Setting}

The site is located in the modern Post Oak Savannah (Diggs et al. 2006) (Figure 2). The Post Oak Savannah is a narrow strip of woodlands between the Pincywoods to the east and south, and the Blackland Prairie vegetational region to the west, north and northwest, no closer than $20 \mathrm{~km}$ away. According to Schmidly (2002:371), the "topography is level to gently rolling and slopes gently from the northwest to the southeast...the post oak region can best be described as an ecotone between the castern deciduous forest and the tall-grass prairie. The area supports a stunted, open forest dotted 


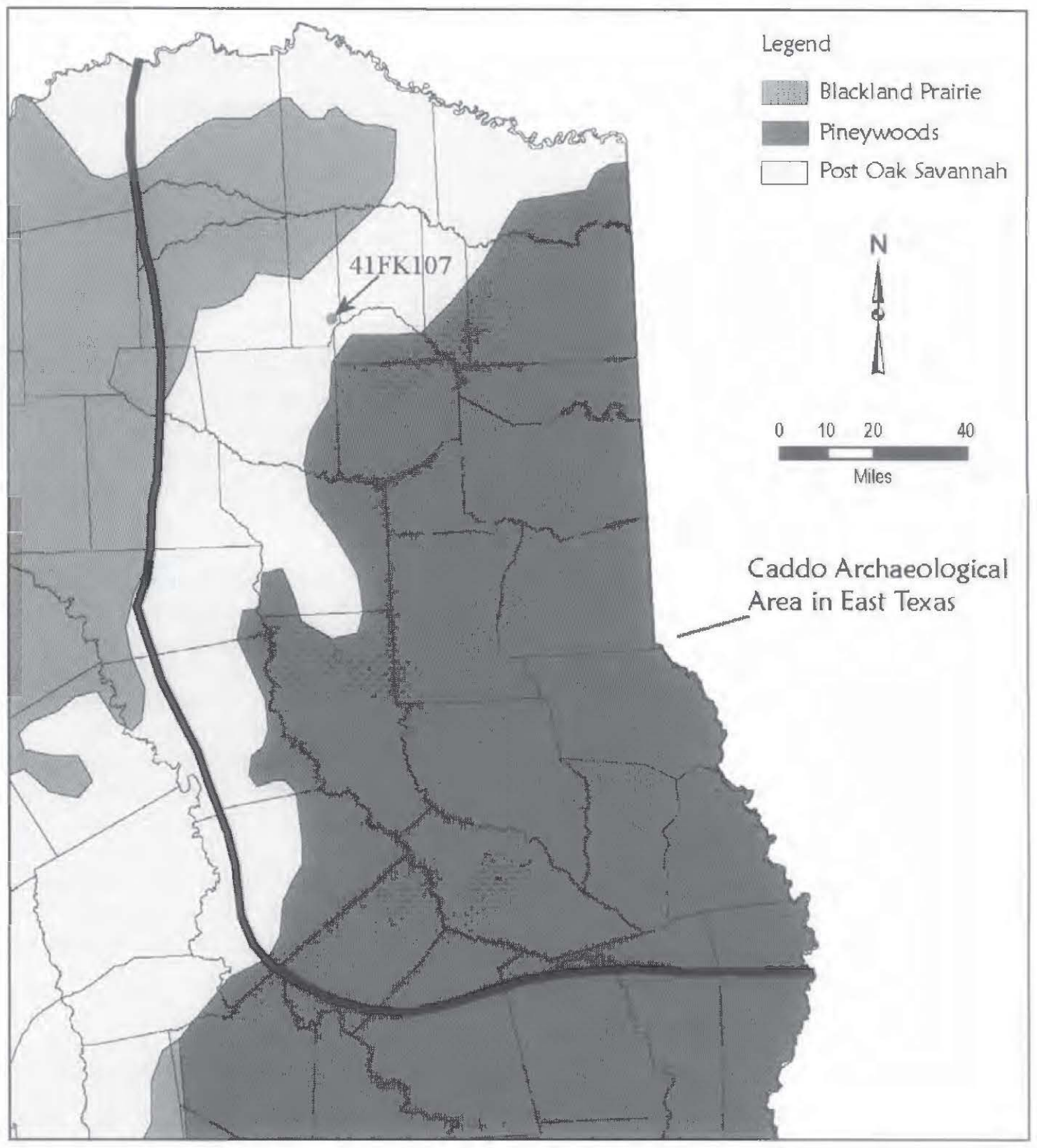

Figure 2. The setting of the New Hope site in the Post Oak Savannah of East Texas.

with small tall-grass prairies. The dominant plants of the overstory are post oak and blackjack oak and to a lesser extent winged elm and black hickory." The Pineywoods have medium-sized to tall broadleaf deciduous forests in more mesic habitats, and shortleaf and loblolly pines are common on upland fine sandy loam soils with adequate moisture. Smaller areas of tall grass prairie may be present in both commumities throughout the region (e.g., Jordan 1981:Figure 4.1), particularly in dricr sandy lands.

The predominant overstory trees in this general locale, prior to mid- $19^{\text {th }}$ century timbering and a general cessation of fire, would have been were red oak ( $Q$ uercus falcata), post oak ( $Q$. stellata), blackjack oak (Q. marilandica), and various species of hickory (Carya sp.), along with sweetgum (Liquidambar styracliflua). Pine trecs probably only occurred in patches. The general composition of the forested landscape on both sides of the Big Cypress Creek would have been an upland woodland of oaks and hickories - with 
more mesic patches of white oak ( $Q$. alba) and red oak - with hardwood forests in the floodplain. The floodplain hardwood forests may have comprised willow oak (Q.phellos), water oak (Q.nigra), overcup oak (Q. lyrata), maple (Acer sp.), sweetgum, ash (Fraxinus sp.), elm (Ulmus americana), and sassafras (Sassafras albidum). There probably were some swampy or marshy, frequently inundated floodplain areas along Big Cypress Creek, and black gum (Nyssa sylvatica) or black tupelo would have been in those settings. Pine was not a primary constituent in the forest. The pine that did occur (probably shortleaf pine, Pinus echninata) would have grown on the drier soils in the forest, likely in patches mixed with blackjack oak and post oak (Bonnicksen 2000:229). The pine was also likely affected by the frequency and intensity of natural or human-created fires. There were patches of prairie, probably areas with poorly drained soils that would have had big (Andropogon gerardii) and little bluestem (Schizachyrium scoparium), switchgrass (Panicum virgatum), and Indiangrass (Sorghastrum sp.) (Marietta and Nixon 1984).

The forest composition prior to European settlement of the Big Cypress Creek valley, in the 1830s1850 s, appears to have been greatly influenced by the frequency and timing of Indian-set and lightningignited fires (see Bonnicksen 2000:331,339). These fires created a mosaic of patches of trees with different tolerances to fire, shade, and moisture. The more-fire-tolerant shortleaf pine was found on drier upland soils, along with the morc fire resistant post oak and blackjack oak also dominant on the drier soils in the forest.

Post oak and blackjack oaks were the important tree species in the area. The post oak and blackjack oaks would have been found on leached soils on poorly drained upland landforms with a low clay content, and there would have had a sparse floor understory cover.

Moister slopes and other upland landforms, along with elevated alluvial landforms (as at the New Hope site), apparently tended to have trees that were moderately tolerant of fire. This would have included loblolly (Pinus taeda), red oak, white oak, and hickory, along with maple, walnut (Juglans nigra), and other hardwoods. The white and red oak were nut-bearing trees. This forest mosaic tended to have a greater diversity of species in canopy than the post oak-blackjack oak or pine forests (Marietta and Nixon 1983). The distribution of mesic forests appears to have been comparable on both sides of Big Cypress Creek. Hickory, in particular, preferred moist slopes as well as river bottoms because they are more vulnerable to fires than the oaks and shortleaf pine.

Mid- $19^{\text {th }}$ century General Land Office field notes indicate that Big Cypress Creek had only a 20-28 foot wide channel in this general area, not much different than in modern times. The strcam flowed all year-round. The channels of the smaller tributaries ranged from 6-10 feet in width, and many of these were probably spring-fed, while others only flowed part of the year (Thurmond 1990:16 and Figure 4).

\section{Previous Investigations at the New Hope Site}

The first notice that the New Hope site had a significant archaeological deposit came when Nelson and Perttula (2003:43-44) documented a large collection of prehistoric artifacts in a private collection. These artifacts indicated that the site had been used during Late Paleoindian, Late Archaic, Woodland, and probable Early Caddo times, with a substantial occupation that took place in the Early Caddo period (ca. A.D. 1000-1200); the other periods were marked by diagnostic projectile points.

The Early Caddo assemblage in this first documented collection included 630 sherds, and two effigy vessels with tab tails. Most of the decorated sherds had punctations, many with crescent-shaped fingernail punctations in free or random patterns. Other decorative elements represented in this collection included diagonal and cross-hatched incised lines, triangular and curvilinear incised zones filled with tool punctations, and diagonal and curvilinear engraved lines on carinated bowls and bottles. 
In 2005, an investigation of an area being scraped by the landowner at the New Hope site recovered evidence of about $50 \%$ of a $8.8 \mathrm{~m}$ circular Caddo structure with a central hearth as well as outdoor activity area pits and post holes (Nclson and Perttula 2006:Figure 5). Charred hickory nutshclls from the central hearth have a calibrated age range of A.D. 1280-1420 ( 2 sigma), with calibrated intercepts of A.D. 1310. A.D. 1360, and A.D. 1390. The ceramic sherds from this work have a Middle Caddo stylistic flavor, because red-slipped sherds are relatively common in the decorated sherd assemblage, there are engraved sherds with cross-hatched and hatched zones, as well as hatched ladders-common in Middle Caddo ccramic assemblages in much of East Texas - and punctated, incised, and brushed utility wares are relatively common (Nelson and Perttula 2006:32-33).

Together, these two previous investigations at the New Hope site recovered 816 sherds ( 604 plain and 212 decorated) from the prehistoric Caddo occupations there. The plain to decorated sherd ratio (P/DR) is 2.85. Utility wares with punctated and incised decorations dominate the assemblage. accounting for $75.9 \%$ of all the decorated sherds (Table 1), while fine wares only comprise $17.5 \%$ of the assemblage. Sherds from brushed vessels, which began to be made and decorated by Caddo potters after ca. A.D. 1200-1300 in the Big Cypress Creek basin, represent only $2.4 \%$ of the decorated sherds at the New Hope sitc. In the Big and Little Cypress Creek basin. pre-A.D. 1200 Caddo sites do not have brushed utility ware ceramics. Utility wares are dominated by punctated, incised, and punctated-incised elements and motifs, and various kinds of engraved fine wares. There appears to be an west to east trend in the manufaeture and use of brushed utility wares in post-A.D. 1200 Caddo sites in the Big Cypress Creek basin, from less than $5 \%$ in the western part of the basin (at sites like New Hope) to as much as $75 \%$ in the eastern part of the basin.

Table 1. Decorated sherds from previous investigations at the New Hope site.

\begin{tabular}{|c|c|c|}
\hline Decorative Method & No. & Percent \\
\hline \multicolumn{3}{|l|}{ Utility Wares } \\
\hline P'unctated & 120 & 56.6 \\
\hline Incised & 41 & 19.3 \\
\hline Incised-Punctaled & 5 & 2.4 \\
\hline Brushed & 5 & 2.4 \\
\hline Pinched & 2 & 0.9 \\
\hline Appliqued & 1 & 0.5 \\
\hline Lip Notched & 1 & 0.5 \\
\hline Subtotal, utility wares & 175 & 82.5 \\
\hline \multicolumn{3}{|l|}{ Fine Wares } \\
\hline Engraved & 31 & 14.6 \\
\hline Red-slipped & 5 & 2.4 \\
\hline Ripley Engraved* & 1 & 0.5 \\
\hline Subtotal, fine wares & 37 & 17.5 \\
\hline Totals & 212 & 100.0 \\
\hline
\end{tabular}

*from Late Caddo Titus phase use of the New Hope site 


\section{Ceramic Assemblage}

The most recently documented Caddo ceramic sherd assemblage documented from the New Hope site has 2045 sherds. Approximately $68 \%$ of the sherds are plain rim, body, and base sherds, while the remainder are decorated rim and body sherds $(n=651)$ from utility ware and fine ware vessels (Table 2$)$. The plain to decorated sherd ratio (P/DR) in this assemblage is 2.14 , which suggests that it is primarily a product of a Middle Caddo occupation (see below). Utility ware sherds comprise $32 \%$ of the rim sherds and $28 \%$ of the body sherds, compared to fine wares, with $23 \%$ of the rim sherds and $4.5 \%$ of the body sherds. These proportions suggest that utility wares are equally decorated on the rim and body of vessels, while fine wares were more likely to have only been decorated on the vessel rim.

Table 2. Composition of newly documented ceramic assemblage from the New Hope site.

\begin{tabular}{lllll}
\hline Decorative Method & Rim & Body & Base & N \\
\hline Plain & 43 & 1241 & 110 & 1394 \\
Utility Ware, Summary & 30 & 516 & - & 546 \\
Appliqued & - & 1 & - & 1 \\
Pinched & - & 2 & - & 2 \\
Brushed & - & 15 & - & 15 \\
Incised-Punctated & 3 & 24 & - & 27 \\
Incised & 19 & 101 & - & 120 \\
Punctated & 8 & 373 & - & 381 \\
& 22 & 83 & - & 105 \\
Fine Ware, Summary & - & 13 & - & 13 \\
Red-slipped & 22 & 69 & - & 91 \\
Engraved & - & 1 & - & 1 \\
Trailed & & & & 2045 \\
& 95 & 1840 & 110 & \\
\hline Totals & & & & \\
\hline
\end{tabular}

Most of the utility warc sherds are from vessels decorated with punctations or incised lines, apparently on both the rim and the vessel body. Among the fine wares, sherds from engraved vessels are hest represented in the collection (sce Table 2).

\section{Plain Sherds and Technological Features of all Ceramic Wares}

The number $(n=43)$ and proportion $(45 \%)$ of plain rims in the New Hope site ceramic collection indicates that plain vessels were an important part of the Caddo ceramic assemblage. Plain vessels include bowls, carinated bowls, botlles, and jars.

The plain vessels at the site are moderate in size, based on orifice diameters of $4.0 \mathrm{~cm}$ for bottle rims and orifice diametcrs that range from $10-20 \mathrm{~cm}$ for non-bottles (Table 3). The small sample of measurable rims indicates that there is little difference in the mean size of the plain, utility, and fine ware non-bottles, as the means range only from $14.1-15.0 \mathrm{~cm}$, with the utility wares only about 5-6\% larger on average than the plain wares and fine wares. The median rim orifice diameter is $14.0 \mathrm{~cm}$. 
Table 3. Rim orifice diameters.

\begin{tabular}{|c|c|c|c|}
\hline $\begin{array}{l}\text { Orifice diameter } \\
(\mathrm{cm})\end{array}$ & Plain ware & Utility ware & Fine ware \\
\hline \multicolumn{4}{|l|}{ Bottles } \\
\hline 4 & $18.2^{*}$ & - & 20.0 \\
\hline \multicolumn{4}{|l|}{ Other Vessel Forms } \\
\hline 10 & 9.1 & - & - \\
\hline 11 & 9.1 & - & \\
\hline 12 & 9.1 & 33.3 & 20.0 \\
\hline 13 & - & - & 10.0 \\
\hline 14 & 18.2 & - & 30.0 \\
\hline 15 & 18.2 & 16.7 & - \\
\hline 16 & - & 33.3 & - \\
\hline 18 & 9.1 & 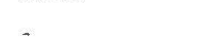 & - \\
\hline 19 & & 16.7 & 20.0 \\
\hline 20 & 9.1 & - & - \\
\hline Mean Orifice Diameter & 14.3 & 15.0 & 14.1 \\
\hline Totals & 11 & 6 & 10 \\
\hline
\end{tabular}

The vast majority of the rim and lip profilcs of the New Hope site vessels are direct (vertical) rims and rounded lips; this is particularly the case among the plain wares and utility wares (Tablc 4). Folded lips whether folded to the exterior or interior-are primarily a feature of engraved fine ware vessels (27.1\%); folded lips are absent among utility warcs and comprise only $4.7 \%$ of the plain wares (probably from plain carinated bowls). Flat lips are present in all tbree wares, but are most abundant among the fine wares (18.1\%). Finally, a small proportion of everted vessel rims are present among all three wares, with the higher proportion present in the utility wares.

Table 4. Kim and lip profiles.

\begin{tabular}{|c|c|c|c|}
\hline Rim and lip profiles & Plain ware & Utility ware & Fine ware \\
\hline Direct-rounded & $74.4 *$ & 71.4 & 54.5 \\
\hline Direct-rounded, ext. folded & 4.7 & - & 18.2 \\
\hline Direct-rounded, int. folded & - & - & 4.5 \\
\hline Direct-flat & 9.3 & 7.1 & 13.6 \\
\hline Direct-flat, ext. folded & - & - & 4.5 \\
\hline Everted-rounded & 4.7 & 7.1 & 4.5 \\
\hline- Rounded & 7.0 & 14.3 & - \\
\hline Totals & 43 & 14 & 22 \\
\hline
\end{tabular}


The New Hope ceramic assemblage is dominated by sherds from vessels tempered with grog (crushed sherds or fired clay). Between $92.9-99.2 \%$ of the sherds in the three wares have grog temper, and it is the sole temper in 45.8-53.9\% of the sherds (Table 5). Other important tempers include burned bone and hematite. Burned bone is present as a temper in $40-42.9 \%$ of the sherds, typically along with grog, while hematite was used as a temper in 5.2-9.9\% of the plain wares and utility wares; none of the fine wares had hematite temper.

Table 5. Use of temper in the ceramic vessel sherds.

\begin{tabular}{llll}
\hline Temper and Paste & Plain ware & Utility ware & Fine ware \\
\hline grog & $45.8^{*}$ & 53.9 & 46.4 \\
grog-sandy paste & 4.5 & 2.6 & 7.1 \\
grog-organics & 1.0 & - & - \\
grog-organics-sandy paste & - & - & 3.6 \\
grog-bone & 35.2 & 36.5 & 28.6 \\
grog-bone-sandy paste & 0.6 & 1.7 & 7.1 \\
grog-bone-organics & 1.0 & - & - \\
grog-hematite & 6.1 & 3.5 & - \\
grog-hematite-organics & 0.3 & - & - \\
grog-bone-hematite & 2.6 & 0.9 & - \\
bone & 0.6 & - & 7.1 \\
bone-sandy paste & 0.3 & - & - \\
bone-organics & 1.0 & - & - \\
bone-organics-sandy paste & 0.3 & - & - \\
bone-hematite & 1.0 & 0.9 & \\
Summary, sherds with: & & & 92.9 \\
grog temper & 96.8 & 99.2 & 42.9 \\
bone temper & 42.5 & 40.0 & - \\
hematite temper & 9.9 & 5.2 & 3.6 \\
organics & 3.5 & - & 17.9 \\
sandy paste & 5.5 & 4.3 & 28 \\
& & & \\
\hline Totals & 313 & & \\
\hline
\end{tabular}

* =percentage

Fine wares tended to be made more often from a naturally sandy clay, as $17.9 \%$ of the fine ware sherds analyzed in detail have a sandy paste (see Table 5). Only 4.3-5.5\% of the plain ware and utility ware sherds have a sandy paste. The vast majority of the sherds are from vessels with a silty to clayey paste, and the clays used for vessel manufacture likely came from sources within 1-7 km of the site, where clays could be readily procured.

Caddo vessels tended to be fired in a variety of different ways, presumably reflecting personal preferences in firing, the desired vessel color, the kind of clays that were used, and the functional and technological requirements of the kinds of vessel forms that were being manufactured at a specific site. Vessels were likely fired in an open fire, with the vessels either set atop the fire or nestled in the coals and ash; vessels would be left in the fire and ashes to cool down or they would have been pulled away from the fire and hot ashes to cool in the open air. The New Hope site Caddo ceramics were most commonly reduced fired (i.e., in a low oxygen firing condition) (Table 6), particularly the fine wares. Between $72.9-82.1 \%$ of the analyzed plain ware and fine ware sherds were fired in a reducing environment, compared to only $55.4 \%$ of the utility wares. 
In the reduced firing employed by the Caddo potters at the site, near the end of the firing, the vessels were apparently pulled or moved away from the fire and allowed to cool in the open air, leaving a thin oxidized 7.one at either one or both vessel surfaces and core.

Vessels fired and coolcd in the open air (i.e., oxidized) were relatively common among the three wares, ranging from 14.3-19.7\% (see Table 6). Conversely, sherds from vessels that were incompletely (and probably poorly fired) oxidized during firing were most common among the utility wares $(15.1 \%)$ and plain wares $(7.8 \%)$, while only $3.6 \%$ of the fine ware sherds were fired in this manner. Fine wares were likely fired at higher temperatures than the other wares, and for a longer duration, producing strong and durable vessels used for the serving of foods and liquids as well as for display. The plain wares and utility wares had more utilitarian uses and they did not apparently require the highest or lengtbiest firing temperatures.

Table 6. Firing conditions in the ceramic vessel sherds.

\begin{tabular}{|c|c|c|c|}
\hline Firing conditions & Plain ware & Utility ware & Fine ware \\
\hline A (oxidized) & $15.2^{*}$ & 19.7 & 14.3 \\
\hline $\mathrm{B}$ (reducing) & 13.1 & 3.6 & 10.7 \\
\hline $\mathrm{C}$ & 3.2 & 6.2 & - \\
\hline D (incompletely & 0.4 & 0.9 & . \\
\hline E oxidized) & 4.2 & 8.0 & 3.6 \\
\hline F (firing in reducing & 28.7 & 33.0 & 39.3 \\
\hline $\mathrm{G}$ environment, and & 27.2 & 14.3 & 21.4 \\
\hline $\mathrm{H}$ cooled in open air) & 3.9 & 4.5 & 10.7 \\
\hline 1 & - & 0.9 & - \\
\hline J (sooted, smudged, or & 0.3 & 0.9 & \\
\hline $\mathrm{K}$ (refired & 3.5 & 7.1 & - \\
\hline $\mathrm{L}$ & 0.3 & 0.9 & - \\
\hline Totals & 283 & 112 & 28 \\
\hline
\end{tabular}

*percentage

Another indication of differences in firing conditions between the plain wares-utility wares versus the fine wares was in the proportion of sherds that were from vessels sooted, smudged, or refircd; these firing conditions suggest that vessel firing in some cases was not well controlled or carefully done. None of the fine ware sherds were from such vessels, compared to $4.1 \%$ of the plain wares and $9.8 \%$ of the utility wares (see Table 6).

The Caddo sherds are from vessels with moderately thick vessel walls (Table 7). Fine ware vessel sherds are consistently from vessels made thinner than decorated utility ware (20-30\% or about $1-2$ standard deviations) or plain ware (4-14\% difference, less than 1 to 1 standard deviations) sherds. particularly when measured along the rim. These variations in vessel wall thickness are likely related to functional and technological decisions made by Caddo potters in how these different wares were intended to be used in local encampments or households. The less substantiat vessel walls in some of the utility wares would he well suited to the cooking and heating of foods and liquids and, because heat would have been conducted 
efficiently while heating rapidly, would have contributed to their ability to withstand heat-related stresses; also, the much thicker utility ware vessels (with rim thicknesses greater than $9 \mathrm{~mm}$ and body wall thicknesses greater than 10-11 mm) would have created stronger and more stable vessels, and would have been well suited for use as long-term storage containers (Rice 1987:227). Fine wares and much of the plain ware were probably intended for use in the serving of foods and liquids, and thinner and less porous vessel walls would have helped to maintain the temperature of served food and liquids; thinner and lighter vessels would have also contributed to the ease with which serving vessels could be handled, used, and transported.

Table 7. Thickness of rim, body, and base sherds.

\begin{tabular}{llll}
\hline Ware & $\begin{array}{l}\text { Rim } \\
(\mathrm{mm})\end{array}$ & $\begin{array}{l}\text { Body } \\
(\mathrm{mm})\end{array}$ & $\begin{array}{l}\text { Base } \\
(\mathrm{mm})\end{array}$ \\
\hline Fine ware & $5.89 \pm 0.67$ & $6.50 \pm 0.87$ & - \\
Utility ware & $7.08 \pm 1.00$ & $8.70 \pm 1.07$ & - \\
Plain ware & $6.11 \pm 1.10$ & $7.43 \pm 0.99$ & $12.1 \pm 1.63$ \\
\hline
\end{tabular}

Another factor that would have influenced vessel body wall thickness would have been the sequence in which a vessel was constructed (Krause 2007:35), of which there are a wide variety of choices available to potters (cf. van der Leeuw 2002:243-256). Vessels constructed from the bottom up, as most Caddo vessels likely were, would tend to have thinner walls moving up the vessel body towards the rim, with the lower portion of the vessel-especially the base, likely made separately, and thus available to serve as a support during later vessel construction - usually significantly thicker than the upper portions of the vessel.

\section{Decorated Sherds}

The utility wares in this collection from the New Hope site include sherds from appliqued, brushed, incised, incised-punctated, pinched, and punctated vessels. The vessels with punctated and incised decorations are particularly abundant in the assemblage.

\section{Appliqued}

The one appliqued sherd is from the body of a jar. It has a single straight appliqued fillet, a fillet that probably divided the body into diffcrent panels, as with Pease Brushed-Incised. There is no evidence on this small sherd as to whether the appliqued panel was decorated or left plain.

\section{Brushed}

The brushed body sherds are from at least five different vessels, based on temper and firing conditions. The majority of the brushed sherds (87\%) have parallel brushing marks; the orientation of the brushing on thesc sherds is not known with certainty. One other brushed sherd has vertical brushing marks on the body of a cooking jar, while the last brushed sherd has overlapping brushing marks.

\section{Incised}

The incised sherds appear to be from utility ware jars. These 120 sherds comprise $63 \%$ of the utility ware rims and about $20 \%$ of the utility ware body sherds (see Table 2), indicating that incised decorated vessels are an important part of the New Hope site ceramic assemblage (Table 8). The rim sherds are dominated by diagonal and diagonal opposed incised lines (accounting for $74 \%$ of the incised rims) that would have run around the vessel rim, as well as rims with cross-hatched, horizontal, and vertical incised lines (Figurc 3a-h). Utility ware typological possibilities for these rim sherds include Canton Incised, Davis Incised, and Dunkin Incised, as well as Kiam Incised (see Suhm and Jclks 1962). These are types that are found in Early to Middle Caddo (ca. A.D. 900-1300) contexts in East Texas. 


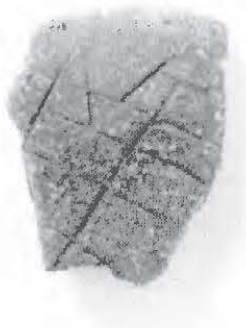

a

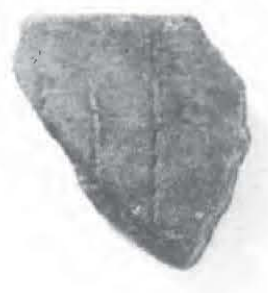

$\mathrm{b}$

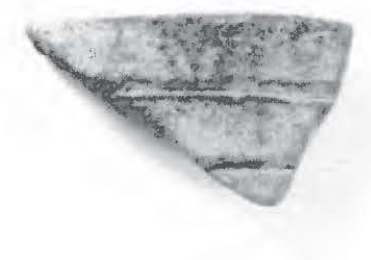

$\mathrm{C}$

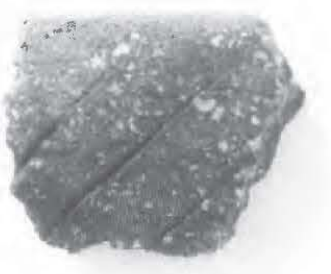

$\mathrm{d}$
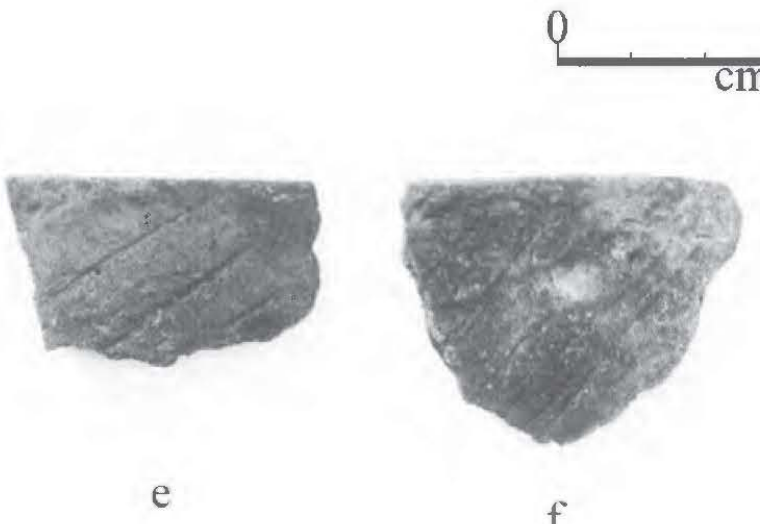

f

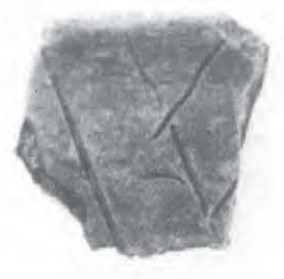

$\mathrm{g}$

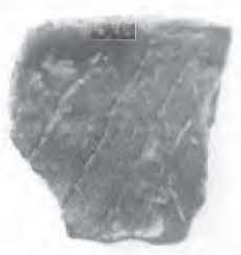

$\mathrm{h}$

Figure 3. Incised rims from the New Hope site ceramic assemblage: a, diagonal opposed panels; b, vertical incised; $c$, horizontal incised; d-f, diagonal; g-h, diagonal opposed incised lines.

Table 8. Incised decorative elements.

\begin{tabular}{llll}
\hline Decorative element & Rim & Body & N \\
\hline Cross-hatched lines & 2 & 5 & 7 \\
Curvilinear lines & - & 1 & 1 \\
Diagonal lines & 10 & 1 & 11 \\
Diagonal-horizontal lines & - & 1 & 1 \\
Diagonal opposed lines & 4 & 12 & 16 \\
Horizontal lines & 2 & - & 2 \\
Parallel lines, none overhanging & - & 1 & 51 \\
Triangular element & - & 1 & 1 \\
Vertical lines & 1 & 28 & 2 \\
Single straight line & - & & 28 \\
& & 101 & 120 \\
\hline Totals & 19 & & \\
\hline
\end{tabular}

Incised body sherds feature simple geometric elements, particularly diagonal opposed and straight lines (Figure 4a, d), as well as cross-hatched (Figure 4c) and parallel lines. Only $1 \%$ of the incised body sherds have curvilinear incised lines (see Table 8 ). 


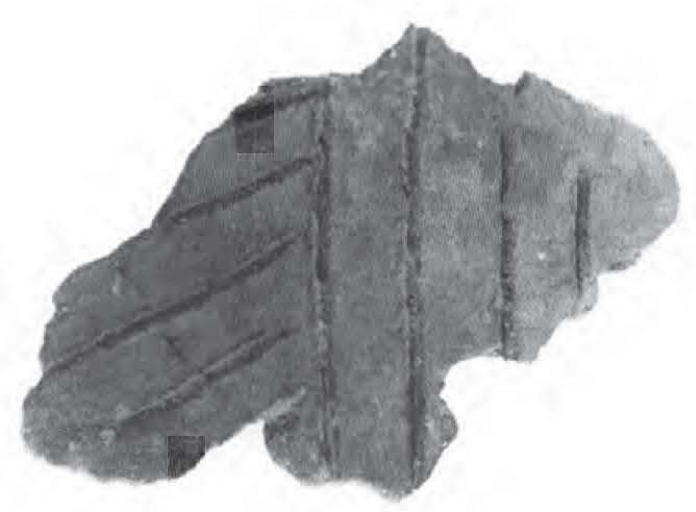

a

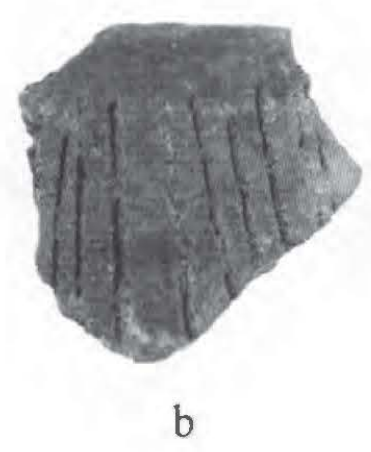

5

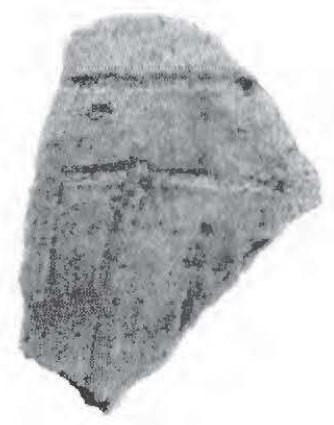

d
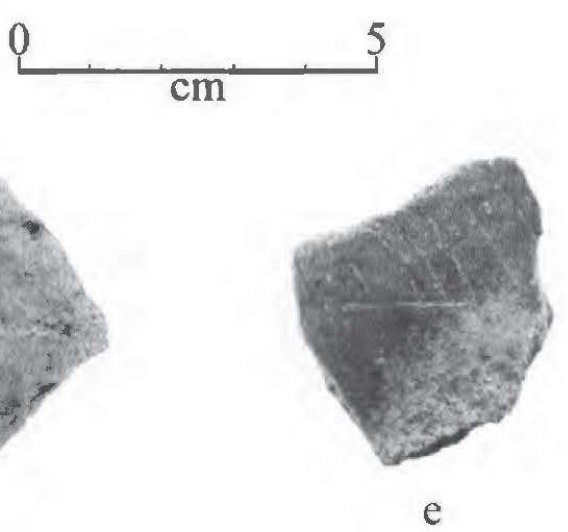

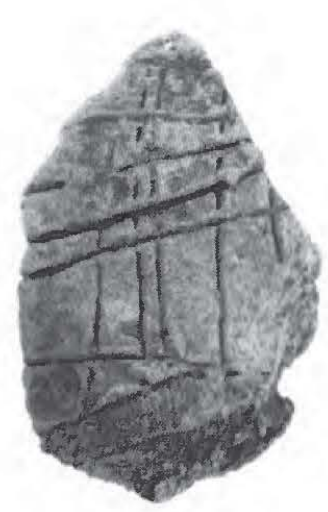

$\mathrm{C}$

Figure 4. Incised body sherds: a, diagonal-opposed, with suspension hole; b, vertical incised; c, cross-hatched; d, diagonal opposed; e, diagonal and horizontal lines.

\section{Incised-Punctated}

Sherds from incised-punctated utility ware vessels represent approximately $5 \%$ of the utility wares in the New Hope site collection, including 13\% of the rim sherds (see Table 2). The punctations are either tool $(n=21)$, fingernail $(n=3)$, circular $(n=2)$, or tool and circular $(n=1)$ elements.

The rim sherds are split evenly between those with curvilinear incised elements and tool or circular punctate-filled curvilinear incised zones (Table 9 and Figure 5a-b) and those with either horizontal or diagonal incised lines and punctations (Figure $5 \mathrm{c}$ ). The latter rim has diagonal incised lines and a triangular incised zone filled with fingernail punctations, while the horizontal incised rim has incised lines above a zone of tool punctations (Kiam Incised).

The incised-punctated body sherds have geometric incised elements, primarily diagonal, horizontal, and parallel lines, and several different punctated elements. These include punctate-filled triangles (see Figure 5e), others with at least one row of punctates above diagonal or diagonal-horizontal lines (see Figure 5d, f), or zones of punctations adjacent to parallel or straight incised lines; the punctated zones are probably incised triangles. Canton Incised and Dunkin Incised vessels have decorations consistent with what we have documented in the incised-punctated sherds from the New Hope site. 


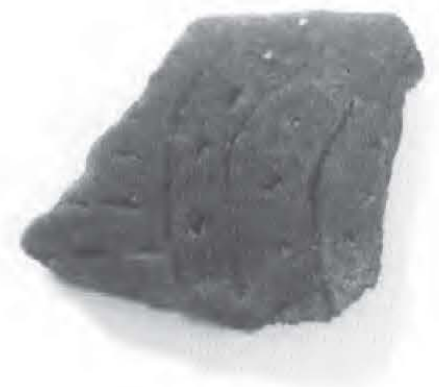

a

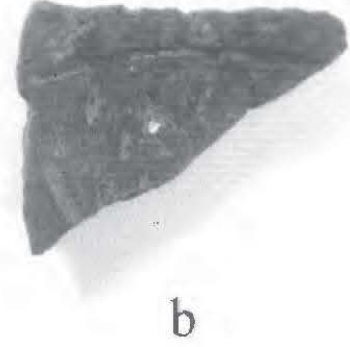

0
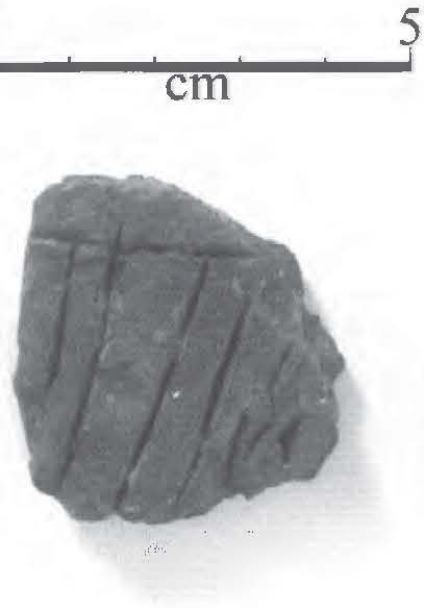

e

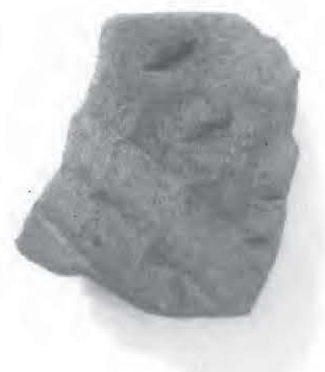

$\mathrm{c}$

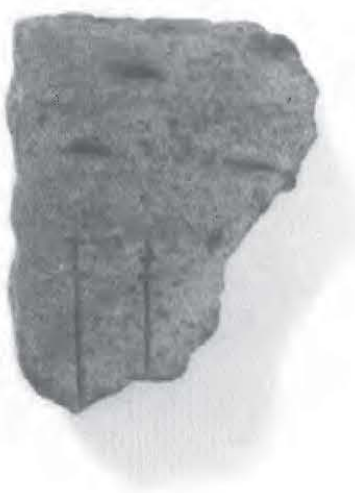

d

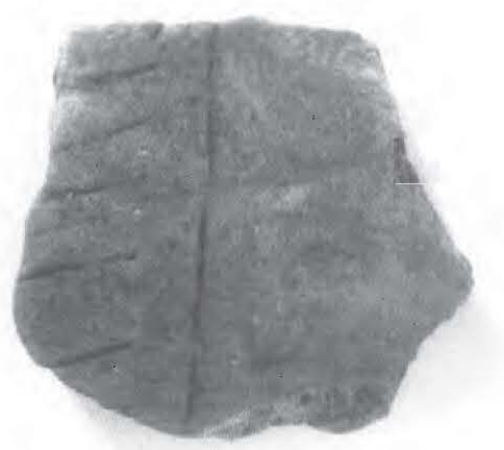

f

Figure 5. Incised-punctated sherds: a, c, rim sherds; b, d-f, body sherds.

Table 9. Incised-punctated decorative elements.

\begin{tabular}{llll}
\hline Decorative element & Rim & Body & N \\
\hline $\begin{array}{l}\text { Curvilinear incised lines with zones of } \\
\text { circular and tool punctates }\end{array}$ & 1 & - & 1 \\
$\begin{array}{c}\text { Curvilinear incised lines with zones of } \\
\text { tool punctates }\end{array}$ & 1 & - & 1 \\
$\begin{array}{l}\text { Diagonal incised lines and fingernail } \\
\text { punctated zone }\end{array}$ & 1 & 1 & 2 \\
$\begin{array}{l}\text { Diagonal incised line above circular } \\
\text { punctated row }\end{array}$ & - & 1 & 1 \\
$\begin{array}{l}\text { Diagonal incised lines adjacent to tool } \\
\text { punctated zone }\end{array}$ & - & 2 & 2 \\
$\quad \begin{array}{l}\text { Horizontal incised lines above tool } \\
\text { punctated zone }\end{array}$ & 1 & - & 1 \\
$\begin{array}{c}\text { Horizontal-diagonal incised lines and } \\
\text { adjacent tool punctated zone }\end{array}$ & - & 2 & 2 \\
$\begin{array}{c}\text { Parallel incised lines adjacent to row of } \\
\text { small circular punctates }\end{array}$ & - & 1 & 1
\end{tabular}


Table 9., cont.

\begin{tabular}{llll}
\hline Decorative element & Rim & Body & N \\
\hline $\begin{array}{c}\text { Parallel incised lines adjacent to tool } \\
\text { punctated zone }\end{array}$ & - & 6 & 6 \\
$\begin{array}{l}\text { Straight incised line between fingernail } \\
\text { punctates }\end{array}$ & - & 1 & 1 \\
$\begin{array}{c}\text { Straight incised line adjacent to tool } \\
\text { punctated zone } \\
\text { Straight incised line adjacent to tool } \\
\text { punctated row } \\
\begin{array}{c}\text { Straight incised line between tool } \\
\text { punctated rows }\end{array}\end{array}$ & - & 5 & 5 \\
\hline Totals & - & 2 & 2 \\
\hline
\end{tabular}

\section{Pinched}

Both pinched body sherds have parallel pinched ridges that cover the vessel surface. These sherds may be from Hollyknowe Ridge Pinched vessels, where the decoration consists of "vertical ridges formed by fingernail pinching" (Webb and McKinney 1975:84).

\section{Punctated}

The sherds with punctated decorations account for $26.7 \%$ of the utility ware rims and $73 \%$ of the utility ware body sherds (see Table 2). The disproportionate number of body sherds to rim sherds suggests that punctated decorations were most commonly placed on the body of cooking and storage jars. The punctated rims have at least one row of either fingernail or tool punctations on them, beginning under the lip and extending to the rim-body juncture (Figure 6a-b).

The sherds with punctations in the New Hope site ceramic assemblage include those with circular punctations (3\%) (Figure 7b-d), fingernail punctations of various sorts (52\%), and tool punctations (39\%) (Table 10). One of the latter body sherds has both horizontal and diagonal tool punctated rows (Figure 7a).

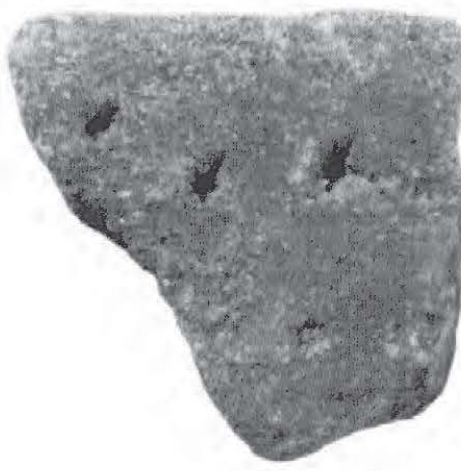

a
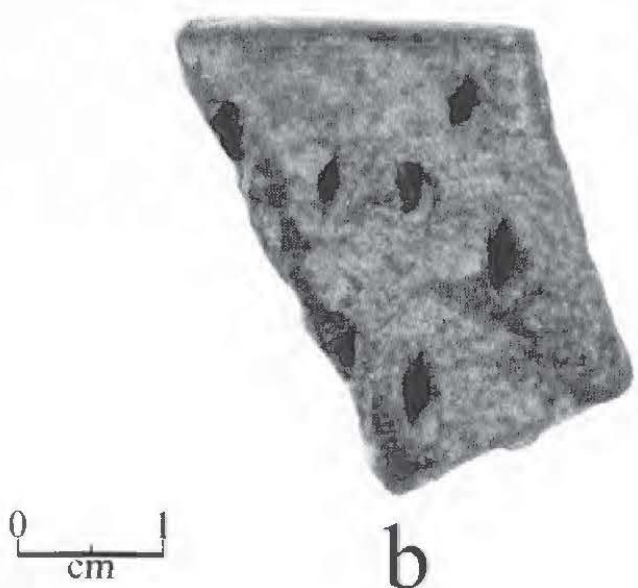

b

Figure 6. Punctated rim sherds. 


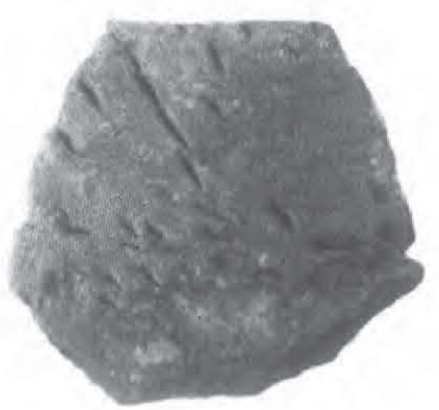

a
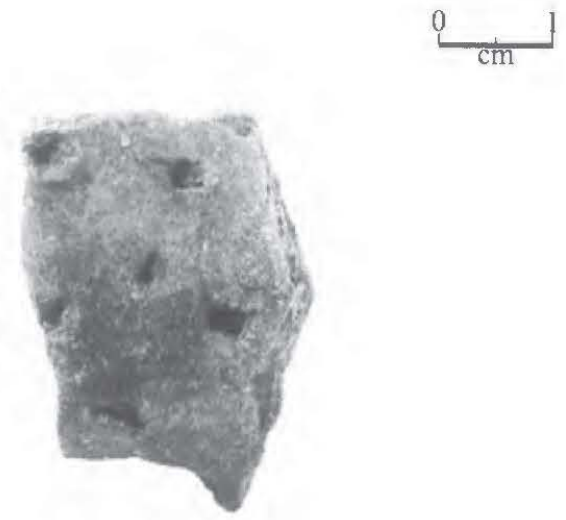

c

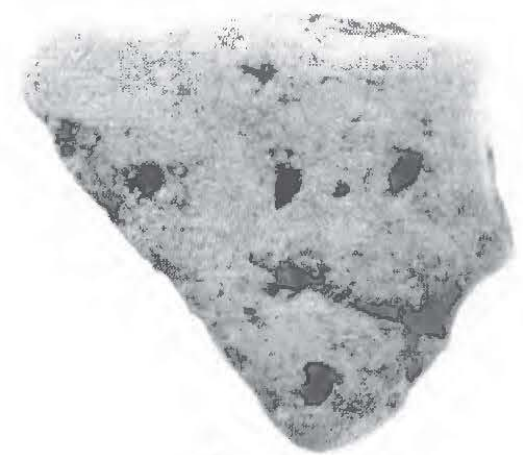

b

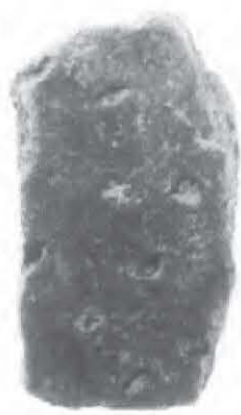

d

Figure 7. Punctated body sherds: a, horizontal and diagonal tool punctated rows; b-d, circular punctated.

Table 10. Punctated decorative elements.

\begin{tabular}{llll}
\hline Decorative element & Rim & Body & N \\
\hline circular punctated & - & 12 & 12 \\
& & 40 & 40 \\
$\begin{array}{l}\text { crescent-shaped fingernail punctations } \\
\text { fingernail punctated rows }\end{array}$ & 2 & - & 2 \\
fingernail punctated, rows and free & - & 156 & 156 \\
horizontal-diagonal tool punctated rows & - & 1 & 1 \\
$\begin{array}{l}\text { tool punctated rows } \\
\text { tool punctated row under lip } \\
\text { tool punctated, rows and free }\end{array}$ & 4 & - & 4 \\
Single punctation, tool/fingernail & - & 143 & 2 \\
& - & 21 & 21 \\
\hline Totals & 8 & 373 & 381 \\
\hline
\end{tabular}


Of the fingernail punctated body sherds, the most distinctive have a crescent-shaped punctation arranged in rows, not bounded by incised lines (Figure 8a-e). These sherds are classified as Weches Fingernail Impressed, var. Alto (Stokes and Woodring 1981:Figures $22 \mathrm{~m}$ and $23 \mathrm{~b}-\mathrm{c}$ ); they represent $10.5 \%$ of the punctated sherds from the site. It may be of temporal significance that there are no Weches Fingernail Impressed, var. Weches sherds in the New Hope site collection (see Stokes and Woodring 1981:181).
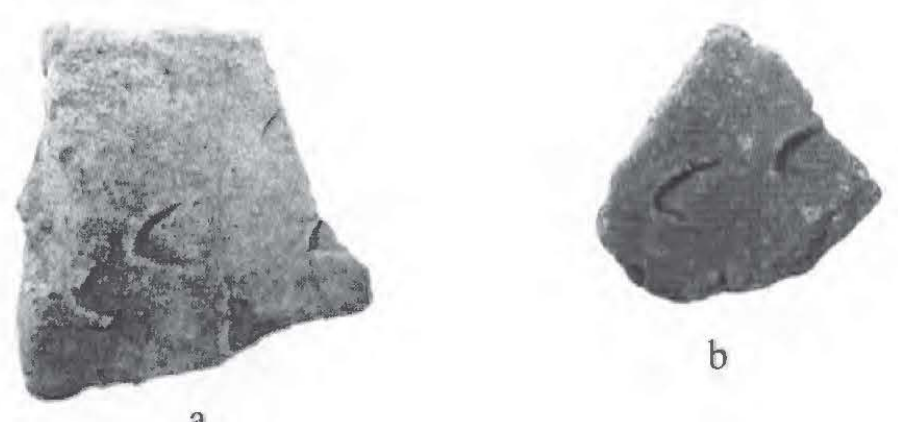

b

a

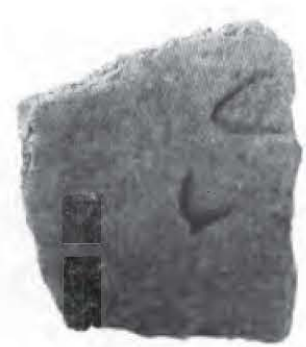

$\mathrm{c}$

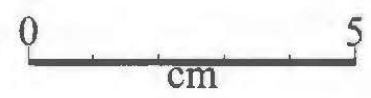

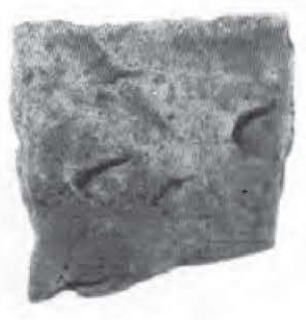

d

Figure 8. Crescent-shaped punctated body sherds from Weches Fingernail Impressed, var. Alto vessels.

The remainder of the punctated sherds include both simple fingernail and tool elements. These have either been arranged in one or more rows, or are freely or randomly distributed across the vessel body (Figures 9a-f and 10a-h). These are probably from Dunkin Incised and Kiam Incised vessels.

The fine wares in the New Hope site ceramic assemblage are vessels with engraved, red-slipped, and trailed decorations. Engraved sherds account for $87 \%$ of the fine wares, followed by red-slipped (12\%), and trailed (1\%) (see Table 2 ). The fine ware rims have only engraved designs.

\section{Engraved}

The engraved sherds from the New Hope site collection have predominantly relatively simple geometric decorations, including diagonal, diagonal opposed, horizontal, parallel, vertical, and triangular elements (Table 11). These decorations occur on bowls and carinated bowls, as well as at least one compound bowl. About $16 \%$ of the sherds have curvilinear lines and concentric elements, and most of the former decorations tend to be on bottles, while concentric semi-circles occur as decorations along the rim panel of carinated bowls. 


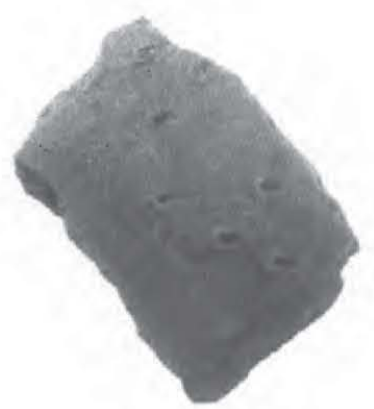

a

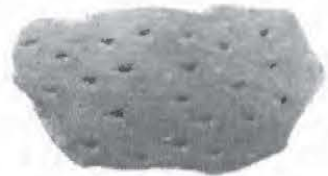

e

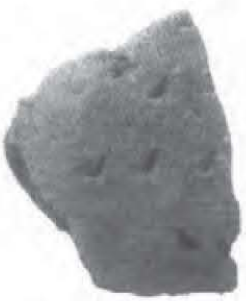

b

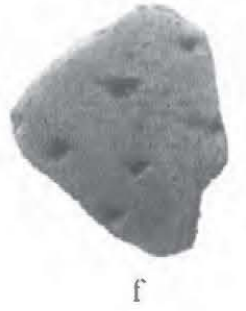

Figure 9. Fingernail punctated body sherds.

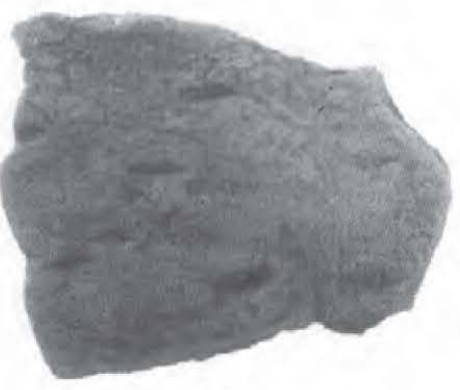

a

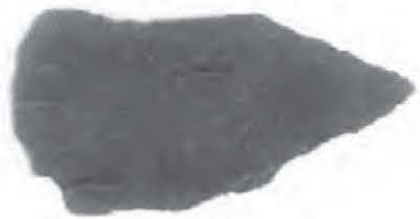

$\mathrm{d}$

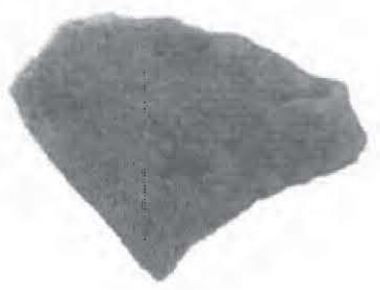

b

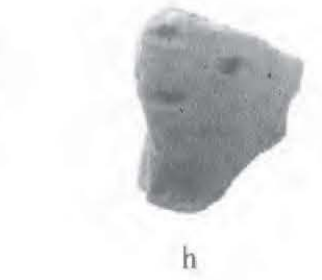

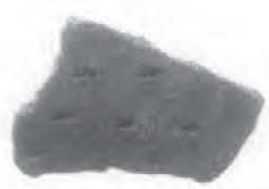

d

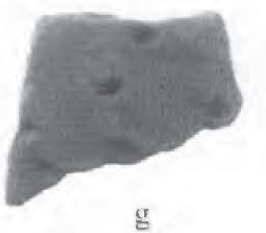

g

$\mathrm{h}$
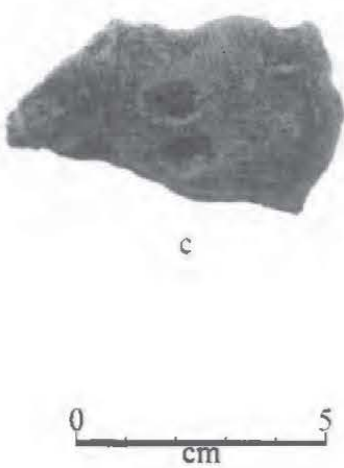

c

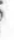


Table 11. Engraved decorative elements.

\begin{tabular}{llll}
\hline Decorative element & Rim & Body & N \\
\hline Concentric semi-circles & 1 & 1 & 2 \\
Cross-hatched zone & - & 1 & 1 \\
Curvilinear lines & - & 8 & 8 \\
Curvilinear, single line & - & 4 & 4 \\
Diagonal engraved lines & 9 & 5 & 14 \\
Diagonal and cross-hatched lines & - & 1 & 1 \\
Diagonal opposed lines & 2 & 5 & 7 \\
Horizontal engraved lines, bottles & 3 & 3 & 6 \\
Horizontal engraved lines, bowls & 4 & - & 4 \\
Horizontal engraved line under lip & 1 & - & 1 \\
Horizontal and curvilinear hatched lines & 1 & - & 1 \\
Horizontal, diagonal opposed, and excised triangle* & 1 & - & 1 \\
Interior straight engraved line & - & 3 & 3 \\
Parallel engraved lines & - & 24 & 24 \\
Straight engraved line & - & 12 & 12 \\
Triangular with hatched lines & - & 1 & 1 \\
Vertical, diagonal opposed, and excised triangle* & - & 1 & 1 \\
\hline Totals & 22 & 69 & 91 \\
\hline
\end{tabular}

*Holly Fine Engraved

Rim sherds are from vessels primarily with diagonal and diagonal opposed engraved lines (Figure 1la-b, f-g), horizontal engraved lines on bottles (Figure 11c-d) and bowls (Figure 11e), or are various combinations of horizontal engraved lines and other elements. One rim is likely from a Holly Fine Engraved vessel (Figure 11h) in that it has fine lines of sets of horizontal and diagonal engraved lines on either side of an excised triangle element (see Suhm and Jelks 1962:Plate 39d). Another distinctive rim has concentric semi-circles (see Table 11).

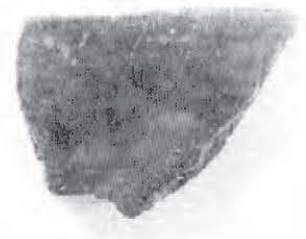

a

\section{0}

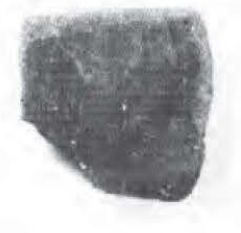

b
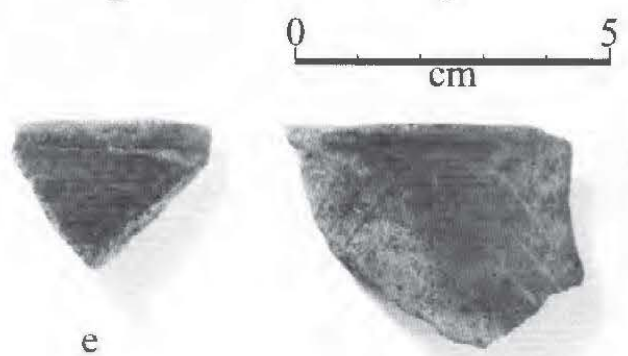

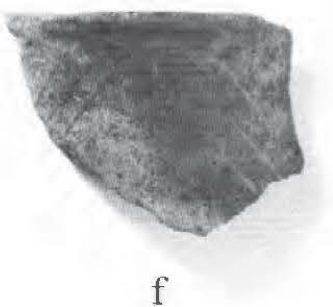

f

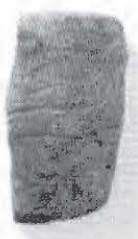

$\mathrm{c}$

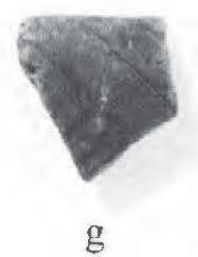

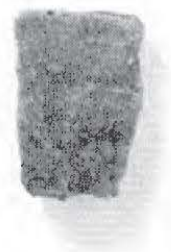

d

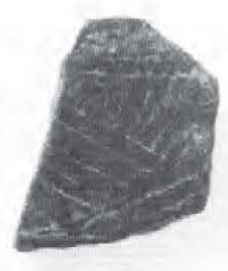

h

Figure 11. Engraved rim sherds: a-b, diagonal engraved; $c-d$, horizontal engraved bottle rims; e, horizontal engraved; f, diagonal opposed engraved; g, diagonal opposed engraved; h, cf. Holly Fine Engraved. 
Engraved body sherds follow the same pattern as the rims, in that the decorative motifs and elements are primarily simple geometric designs (Figure 12d-e), with a few curvilinear engraved sherds from bottles (Figure 12a) as well as concentric semi-circles (Figure 12c; see Table 11). One Holly Fine Engraved body sherd has horizontal and diagonal opposed engraved lines on either side of an excised triangle (Figure 12b).

Only three of the engraved sherds (3\%) in the ceramic assemblage have a pigment rubbed in the engraved lines. This includes two diagonal engraved rims with a red pigment in the lines (see Figure 11a-b), as well as

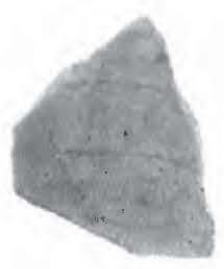

a

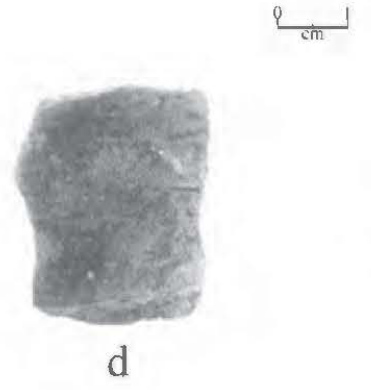

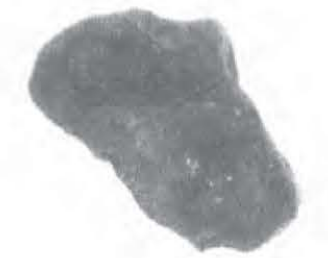

b
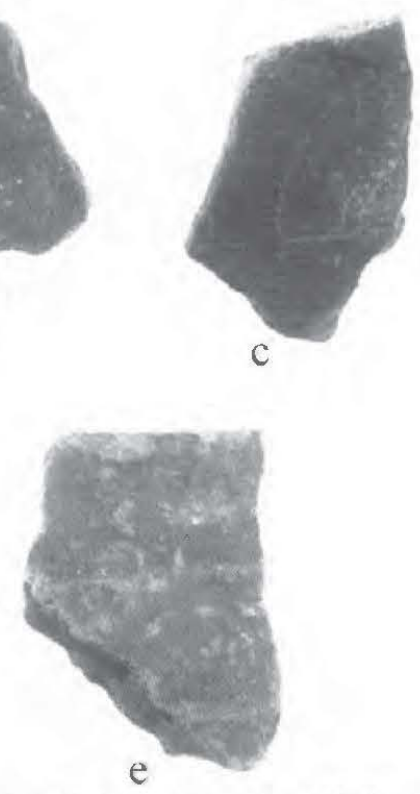

Figure 12. Engraved body sherds: a, curvilinear engraved; b, Holly Fine Engraved; c, concentric semi-circles; d, diagonal opposed engraved; e, parallel engraved lines, compound bowl.

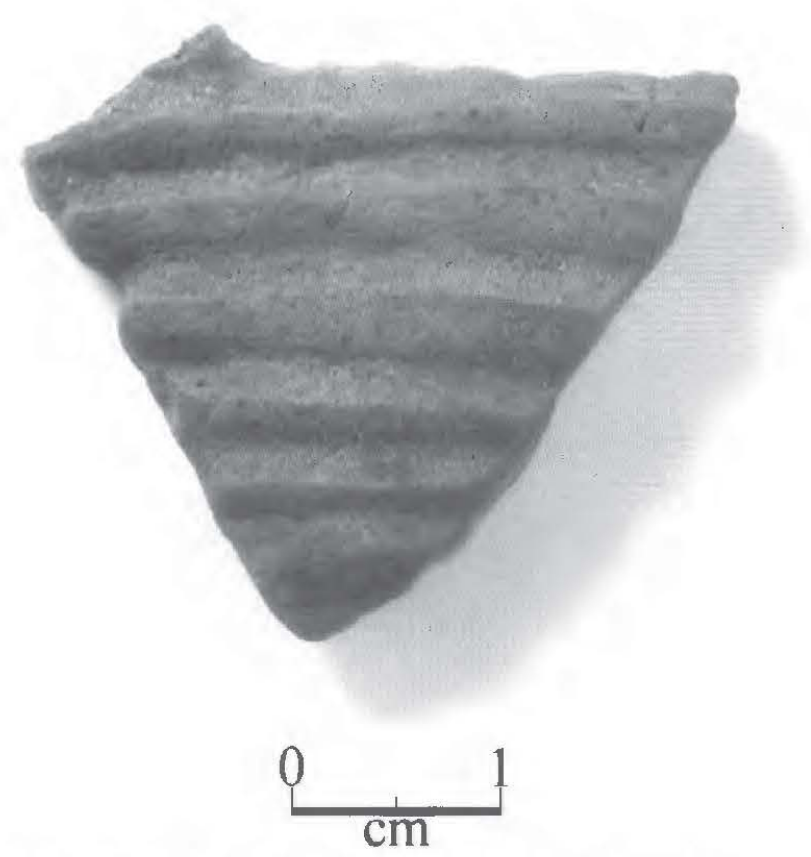

a Holly Fine Engraved rim with red pigment rubbed in the engraved lines (see Figure 11h). One sherd with a cross-hatched engraved zone has also been red-slipped on its interior surface: this is likely from a Late Caddo Titus phase vessel.

\section{Red-slipped}

The red-slipped sherds are from carinated bowls $(n=2)$ or bottles $(\mathrm{n}=11)$. The carinated bowls have $\mathrm{a}$ red slip on both interior and exterior vessel surfaces, while the bottles have a redslip only on the exterior surface. The sherds are from grog-tempered vessels, suggesting they may be classified as Sanders Plain (see Brown 1996).

\section{Trailed}

The one grog-tempered sherd is from a Keno Trailed vessel that has a series of U-shaped curvilinear trailed lines (Figure 13) that apparently covered the body of a bowl (see Suhrn and Jelks 1962:Plate 44f; Webb 1959:Figure 111c). Keno Trailed is a Late Caddo to Historic Caddo pottery type, and is not commonly found in East Texas Caddo archaeological sites, suggesting that the sherd came from a vessel traded into the $\mathrm{Big}$ Cypress Creek basin from another Caddo group in the Red River basin to the east.

Figure 13. Keno Trailed body sherd from the New Hope site. 


\section{Cultural and Temporal Affiliation of the Ceramic Assemblage}

Based on the stylistic motifs and elements identified in this ceramic assemblage documented from the New Hope site, along with the previous analyses of ceramics from the site (Nelson and Perttula 2003, 2006), it appears that the site was primarily occupied by Caddo Indian peoples between ca. A.D. 900-1400. This occupation probably took place on at least two different occasions during this broad temporal interval, rather than as a continuous occupation lasting several centuries. There also is very limited evidence for a Late Caddo occupation possibly post-dating ca. A.D. 1600, based upon the recovery of Ripley Engraved and Keno Trailed sherds in the various collections.

Both Early Caddo (ca. A.D. 900-1200) and Middle Caddo (ca.A.D. 1200-1400) occupations at the site were residential in nature, based on the range of plain $(n=2210)$, utility $(n=721)$, and fine warcs $(n=142)$ in the ceramic assemblages (Table 12), as well as a large family cemetery (likely of Early Caddo age) and the excavation of a Middle Caddo circular house and associated extramural features (see Nelson and Perttula 2003, 2006). Denoting the Early Caddo ceramics are engraved fine wares from the types Hickory Engraved and Holly Fine Engraved, as well as incised, punctated, and incised-punctated sherds from Davis Incised, Dunkin Incised, Kiam Incised, and Weches Fingernail Impressed. The very high percentage of punctated sherds in the assemblage-especially the proportion of fingernail punctated sherds - is also consistent with much of the ceramic assemblage dating to the Early Caddo period.

Table 12. Decorated sherds from all investigations at the New Hope site.

\begin{tabular}{lll}
\hline Decorative Method & No. & Percent \\
\hline Utility Wares & & \\
Punctated & 501 & 58.1 \\
Incised & 161 & 17.5 \\
Incised-Punctated & 32 & 3.7 \\
Brushed & 20 & 2.3 \\
Pinched & 4 & 0.5 \\
Appliqued & 2 & 0.2 \\
Lip Notched & 1 & 0.1 \\
& & \\
Subtotal, utility wares & 721 & 83.5 \\
Fine Wares & & \\
Engraved & & 14.2 \\
Red-slipped & 22 & 2.1 \\
Ripley Engraved* & 18 & 0.1 \\
Trailed* & 1 & 0.1 \\
Subtotal, fine wares & 1 & 16.5 \\
\hline Totals & 142 & 100.0 \\
\hline
\end{tabular}

\section{*from Late Caddo Titus phase use of the New Hope site}

More indicative of the Middle Caddo period occupation are the small amounts of brushed and red-slipped sherds, sherds from Canton Incised vessels, and distinctive engraved sherds with concentric semi-circles and sherds with hatched zones and ladders (see Nelson and Perttula 2006:33). These kinds of engraved sherds 
were particularly notable in the archaeological deposits excavated to expose the circular house at the New Hope site; the one radiocarbon date from the circular house is cal A.D. 1280-1420 (2 sigma).

\section{Ear Spool}

There is a single sherd from a non-flanged ceramic ear spool among the ceramic artifacts. The piece has roughly straight sides and flattened ends, and is grog-tempered. It is $4.7 \mathrm{~mm}$ thick and $18.8 \mathrm{~mm}$ in length. A very similar ceramic ear spool sherd was documented from the Hudnall Pirtle site (41RK4), an Early Caddo civic-ceremonial center on the Sabine River (Bruseth and Perttula 2006:Figure 29f).

\section{Burned Clay and Daub}

There are 10 pieces of burncd clay and daub in this collection from the New Hope site: three daub (with stick impressions) and seven pieces of burned clay. The low amount of burned clay and daub suggests that no grass-thatched and clay-lined Caddo houses had been burned at the site, thus preserving burned examples of the clay lining. The few pieces at the site probably represent the incidental burning of earth and clay from the use of outdoor fires or earth ovcns.

\section{SUMMARY AND CONCLUSIONS}

The New Hope site is a multiple component prehistoric site in the Big Cypress Creck valley. It is regularly submerged by the waters of Lake Bob Sandlin, but during periods of low water and wave action. artifacts have been exposed along the shoreline at the site. Several collections of prehistoric lithic and ceramic artifacts have been obtained over the last 20 years, and we have documented three such collections from the sitc (Nelson and Perttula 2003, 2006), including the large ceramic assemblage documented in this article. In addition to the principal occupations that took place between ca. A.D. 900-1400 at the site. the recovery of a number of dart points from the site indicate it was used by hunting-gathering foragers in $I$ ate Paleoindian, Late Archaic, and Woodland periods.

The ca. A.D. 900-1400 ceramic assemblage from the New Hope site has grog and grog-bone-tempered sherds from moderately thick plain wares, utility wares, and fine wares. The sherds are from vessels that were fired predominantly in a reducing environment, and many of the vessels were apparently pulled from the fire and allowed to cool in the open air, probably just outside the open firing pit. This left these vesscls with a thin oxidized lens (yellowish-brown or reddish-brown in color) on either onc or both vessel surfaces. Other sherds came from reduced fired vessels with dark grayish-brown to black surface colors.

The proportion of plain rims in the assemblage indicate that a significant number of the vessels made and used at the New Hope were plain ware bottles, jars, and bowls. Among the decorated vessels, morc than $80 \%$ of the sherds are from utility wares decorated with punctated (fingernail and tool), incised, and incised-punctated elements; the punctated sherds dominatc the collection, with $58 \%$ of all the decorated sherds having punctated designs, along with sherds from incised vessels (see Table 12). The fine wares are not well represented in the New Hope ceramic collections, but include sherds from a variety of engraved wares as well as a low percentage of red-slipped sherds.

The decorated sherds in the New Hope site ceramic assemblage indicates that the main Caddo occupations took place between ca. A.D. 900-1400, with the earliest component dating to the Early Caddo period, and the latter component dating to sometime in the Middle Caddo period. More detailed investigations, including controlled surface collections, intensive shovel testing, and selected hand-excavation areas, are warranted at the site to better define and discriminate the spatial extent of each component. as well as to better isolate the character of the ceramics from each component, and to obtain absolute dates from each. 


\section{ACKNOWLEDGEMENTS}

We want to thank Lance Trask for preparing the figures and photo images used in this article.

\section{REFERENCES CITED}

Bonnicksen, T. M.

2000 America's Ancient Forests: From the Ice Age to the Age of Discovery. John Wiley \& Sons, Inc., New York.

Brown, J. A.

1996 The Spiro Ceremonial Center. The Archaeology of Arkansas Valley Caddoan Culture in Eastern Oklahoma. 2 Vols. Memoir No. 29. Museum of Anthropology, University of Michigan, Ann Arbor.

Bruseth, J. E. and T. K. Perttula

2006 Archeological Investigations at the Hudnall-Pirtle Sitc (41RK4): An Early Caddo Mound Center in Northeast Texas. Caddo Archeology Journal 15:57-158.

Diggs Jr., G. M., B. L. Lipscomb, M. D. Reed and R. J. O'Kennon

2006 Illustrated Flora of East Texas, Volume One: Introduction, Pteridophytes, Gymnosperms, and Monocotyledons. Sida, Botanical Miscellany, No. 26. Botanical Research Institute of Texas, Fort Worth.

Jordan, T. G.

1981 Trails to Texas: Southern Routes of Western Cattle Ranching. University of Nebraska Press, Lincoln.

Krause, R. A.

2007 A Potter's Tale. In Plains Village Archaeology: Bison-hunting Farmers in the Central and Northern Plains, edited by S. A. Ahler and M. Kay, pp. 32-40. University of Utah Press, Salt Lake City.

Marietta, K. L. and Nixon, E. S.

1983 Vegetation Analysis of a Post Oak-Black Hickory Community in Eastern Texas. Texas Journal of Science 35:197-203.

1984 Vegetation of an Open, Prairie-Like Community in Eastern Texas. Texas Journal of Science 36:25-34.

Nelson, B. and T. K. Perttula

2003 Archeological Survey along the Lake Bob Sandlin Shoreline, Camp, Franklin, and Titus Counties, Texas. Report of Investigations No. 46. Archeological \& Environmental Consultants, LLC, Austin.

2006 Archaeological Investigations at the New Hope Site (41FK107) at Lake Bob Sandlin, Franklin County, Texas. Journal of Northeast Texas Archaeology 25:26-37.

Rice, P. M.

1987 Pottery Analysis: A Sourcebook. University of Chicago Press, Chicago.

Schmidly, D. J.

2002 Texas Natural History: A Century of Change. Texas Tech University Press, Lubbock. 
Stokes, J. and J. Woodring

1981 Native-Made Artifacts of Clay. In Archeological Investigations at the George C. Davis Site, Cherokee County, Texas: Summers of 1979 and 1980, edited by D. A. Story, pp. 135-238. Occasional Paper No. 1. Texas Archeological Research Laboratory, The University of Texas at Austin.

Thurmond, J. P.

1990 Archeology of the Cypress Creek Drainage Basin, Northeastern Texas and Northwestern Louisiana. Studies in Archeology 5. Texas Archeological Research Laboratory, The University of Texas at Austin.

van der Leeuw, $S$.

2002 Giving the Potter a Choice: Conceptual aspects ol pottery technique. In Technological Choices: Transformation in Material Cultures since the Neolithic, edited by P. Lemonnier, pp. 238-288. Routledge, London.

Webb, C. H.

1959 The Belcher Mound, a Stratified Caddoan Site in Caddo Parish, Louisiana. Memoirs No. 16. Society for American Archaeology, Salt Lake City.

Webb, C. H. and R. R. McKinney

1975 Mounds Plantation (16CD12), Caddo Parish, Louisiana. Louisiana Archaeology 2:39-127.

\section{APPENDIX 1, CHIPPED STONE TOOLS FROM THE NEW HOPE SITE (41FK107)}

A small sample of chipped and ground stone tools are in the newly documented collections from the New Hope site. Most are dart points and bifacial fragments that are the product of the Archaic and Woodland period use of the site, but there are also flake tools, an arrow point, and an ochre pigment stone.

\section{Dart Points}

There are several different types of dart points represented in the documented New Hope site collection. This includes probable Delhi $(n=1)$, Bulverde $(n=3)$, Kent $(n=1)$, Godley $(n=1)$, and Gary, var. Camden $(\mathrm{n}=3)$ points (Figure 14a-h). The Delhi and Bulverde points are indicative of a Late Archaic occupation at

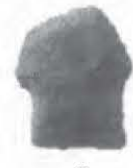

a

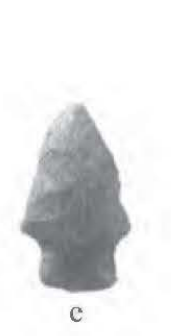

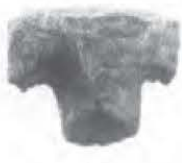

b

0
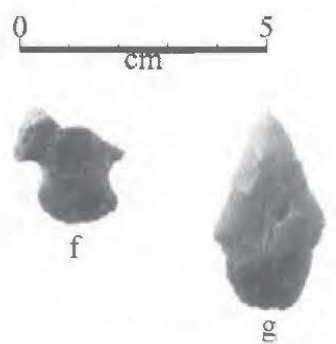
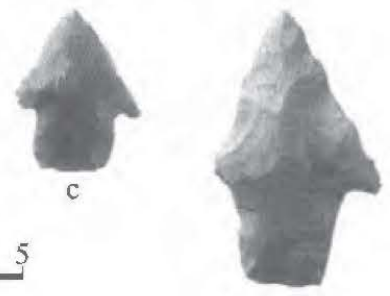

d

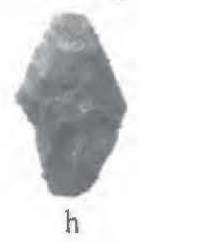

Figure 14. Dart points from the New Hope site: a, c-d, Bulverde; b, Delhi; e, Kent; f, Godley; g-h, Gary, var. Canden. the site,while the Kent (at least in East Texas), Godley, and Gary points are the product of a Woodland period use, probably one that dated after ca. A.D. 200, based on the identilication of the late Gary, var. Camden style (see Schambach 1982).

Specific details regarding the dart points are provided in Table 13. The Bulverde points are made from chert, have wedge-shaped chipped stem bases, and they are considerably resharpened along the blades (see Figure 14a, e-d). The Delhi point has been broken laterally across the blade and there is evidence of an impact lracture as well, it has small downwardpointing barbs, and a wedge-shaped chipped stem base (see Figure 14b). 
Table 13. Dart points from the New Hope site (41FK107).

\begin{tabular}{llllllll}
\hline Type & Raw Material & Flaking Resharpened & $\begin{array}{l}\text { L } \\
(\mathrm{mm})\end{array}$ & $\begin{array}{l}\text { W } \\
(\mathrm{mm})\end{array}$ & $\begin{array}{l}\text { Th } \\
(\mathrm{mm})\end{array}$ & $\begin{array}{l}\text { SW } \\
(\mathrm{mm})\end{array}$ & Figure \\
\hline Bulverde & brown chert & unifacial+ & 26.9 & 21.8 & 5.6 & 16.5 & $14 \mathrm{a}$ \\
Bulverde & brown chert & bifacial+ & 30.7 & 23.9 & 8.9 & 13.7 & $14 \mathrm{c}$ \\
Bulverdel & ight gray chert & bifacial+ & 52.0 & 31.0 & 10.3 & 20.0 & $14 \mathrm{~d}$ \\
Delhi & quartzite & bifacial & $25.2+$ & 32.1 & 9.7 & 15.6 & $14 \mathrm{~b}$ \\
Gary & quartzite & bifacial+ & $37.1+$ & 26.6 & 6.6 & 14.0 & - \\
Gary & grayish-brown & bifacial+ & 38.5 & 20.9 & 6.6 & 15.4 & $14 \mathrm{~g}$ \\
& chert & & & & & & \\
Gary & brown chert & bifacial+ & $35.0+$ & 21.0 & 6.5 & 16.1 & $14 \mathrm{~h}$ \\
Godley & petrified wood & bifacial & $22.2+$ & $21.0+$ & 6.7 & 11.9 & $14 \mathrm{f}$ \\
Kent & quartzite & bifacial+ & 36.0 & 20.5 & 6.8 & 13.2 & $14 \mathrm{e}$ \\
\hline
\end{tabular}

+=present; $\mathrm{L}=$ length; $\mathrm{W}=$ width; $\mathrm{Th}=$ thickness; $\mathrm{SW}=$ stem width

The Gary points have contracting stems and resharpened blades (see Figure $14 \mathrm{~g}-\mathrm{h}$ ), and are made from both quartzite and chert raw materials. They are relatively thin $(6.5-6.6 \mathrm{~mm})$ and narrow $(14.0-16.1 \mathrm{~mm})$ at the stem, which is characteristic of the latest variety of Gary dart point, var. Camden (see Schambach 1982:Table 7-4). The Godley point is made from a local brown petrified wood, and has a lateral fracture across the blade (see Figure 14f). The one Kent dart point has a rectangular stem with a rounded base, as well as a resharpened blade (see Figure 14e). It is made from a local quartzite.

\section{Bifaces and Biface Preforms}

There are six bifaces and biface fragments in this documented New Hope site collection. One of these is a bifacial knive fragment of a gray chert; it is $28.9 \mathrm{~mm}$ wide and $6.9 \mathrm{~mm}$ thick. Three others are thick bifaces shaped by large percussion flakes (Figure 15a-b), and do not have any edge shaping or pressure flaking; two of the three have cortex on one face, and one has a knot of raw material that could not be removed during the flaking (Figure 15b). The thick bifaces were made from a heat-treated quartzite $(n=2)$ and a brown chert $(n=1)$. Dimensions of the thick bifaces range from $40.0-57.8 \mathrm{~mm}$ in length; $24.8-30.0 \mathrm{~mm}$ in width; and 10.8-21.9 $\mathrm{mm}$ in thickness.

The thin biface preforms are ovoid-shaped, with no cortical remnants. They have been shaped by a combination of percussion and pressure flaking around the lateral edges of the preforms (Figure $15 \mathrm{c}-\mathrm{d})$. Both are made from a local quartzite. The thin bifaces range from 10.1-10.2 $\mathrm{mm}$ in thickness, $37.2-46.8 \mathrm{~mm}$ in length, and $33.0-38.6 \mathrm{~mm}$ in width.

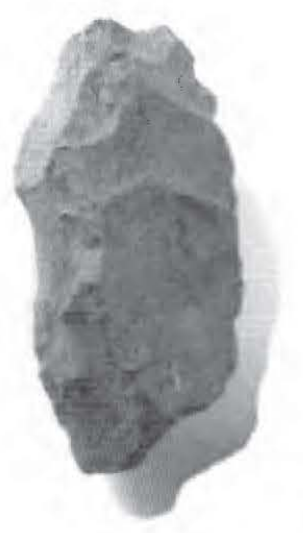

a

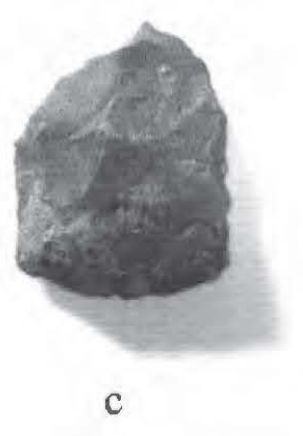

C
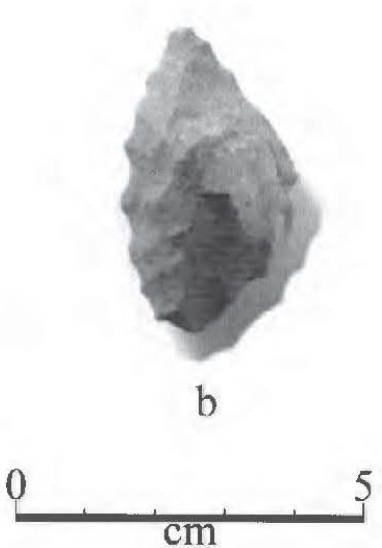

5

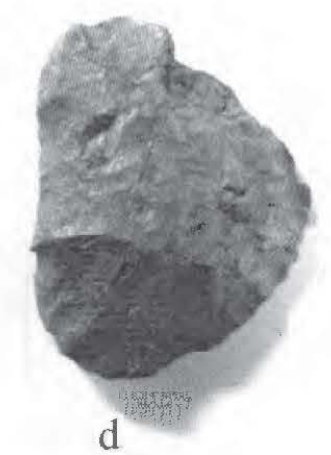

Figure 15. Bifaces from the New Hope site (4IFK107): $a-b$, thick bifaces; $c-d$, ovoid biface preforms. 


\section{Arrow Point}

The single Perdiz arrow point in the collection has a contracting stem and rounded base, a unifacially worked blade, along with serrated blades and small downward-pointing barbs (Figure 16). The point is made from a non-heat-treated local quartzite. The Perdiz point is likely associated with the post-A.D. 1200 use of the New Hope site (cf. Turner et al. 2011:206). The arrow point is $20.0 \mathrm{~mm}$ in length, $10.8 \mathrm{~mm}$ in width, and $2.5 \mathrm{~mm}$ in thickness; its stem width is $5.6 \mathrm{~mm}$.

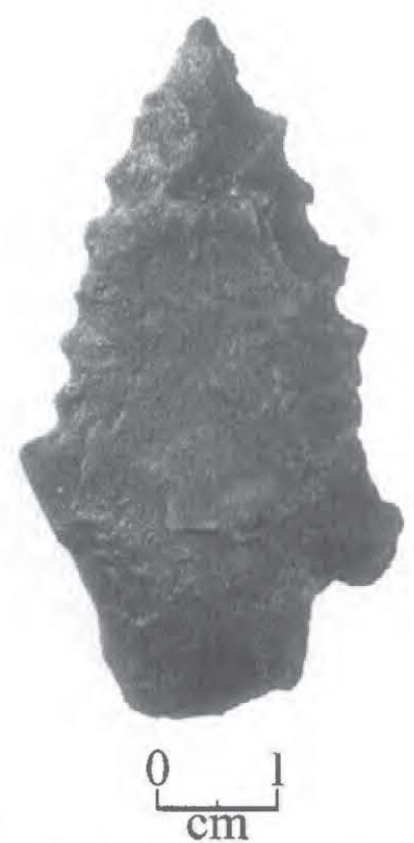

Figure 16. Probable Perdiz arrow point from the New Hope site (41FK107).

\section{Scrapers and Flake Tools}

The collection contains three distal end scrapers (Figure 17a), two of which also have lateral retouch/use-wear (Figure 17b-c). These tools would have been used for scraping hide, as well as cutting and shredding wood, bone, and leather. The tools are manufactured from petrified wood (Figure 17a), grayishbrown chert (Figure 17b), and brown chert (Figure 17c). All three tools are on cortical flakes.

Use-wear length of the scraper edges ranges from 19.0-25.2 $\mathrm{mm}$, while the use-worn/retouched edges have use-wear lengths of $19.0 \mathrm{~mm}$ and $26.9 \mathrm{~mm}$. The flakes themselves range in length from 27.9-39.3 mm, with widths ranging from $26.0-33.1 \mathrm{~mm}$; flake thicknesses range from $5.7-8.6 \mathrm{~mm}$.

\section{Pigment Stone}

One pebble-sized piece of ochre has been used as a pigment stone as there are five grooves cut across the stone, presumably to extract pigment. The pigment stone is $34.2 \mathrm{~mm}$ in length, 20.0 $\mathrm{mm}$ in width, and $9.6 \mathrm{~mm}$ in thickness.

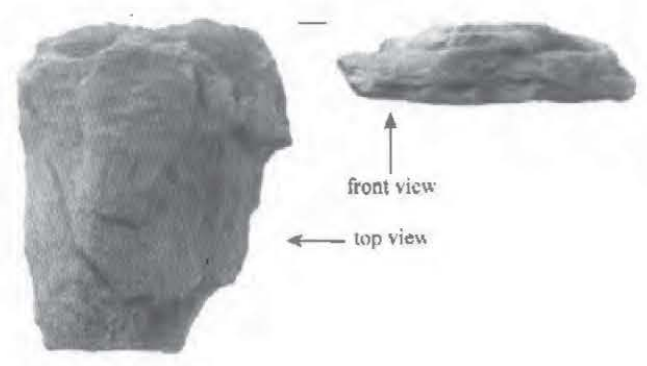

a

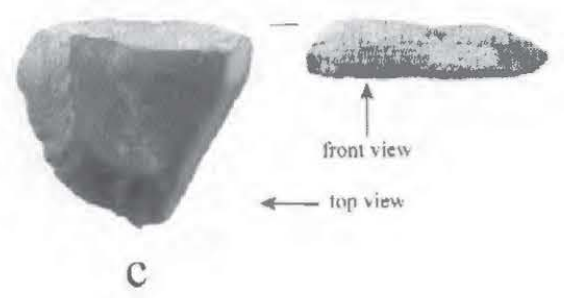

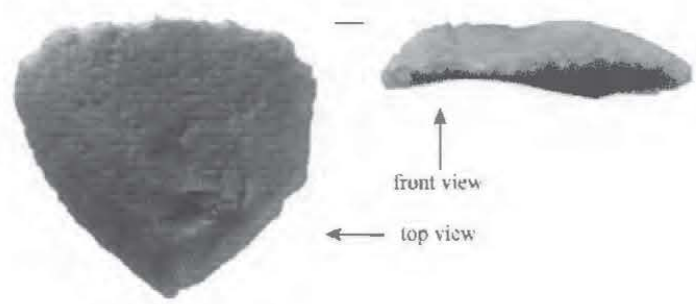

b

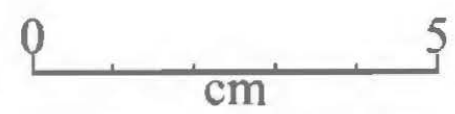

Figure 17. Scrapers and flake tools: a, end scraper; b-c, end scraper and lateral use-wear/retouch tools. 


\section{REFERENCES CITED}

Schambach, F. F.

1982 An Outline of Fourche Maline Culture in Southwest Arkansas. In Arkansas Archeology in Review, edited by N. L. Trubowitz and M. D. Jeter, pp. 132-197. Research Series No. 15. Arkansas Archeological Survey, Fayetteville.

Turner, E. S., T. R. Hester, and R. L. McReynolds

2011 Stone Artifacts of Texas Indians. Taylor Trade Publishing, Lanham, Maryland. 